\title{
SYNTHESIS OF TWO NEW CORTICOTROPHIC PEPTIDES CONTAINING HOMOARGININE IN POSITION 8
}

\author{
BY \\ G. I. TESSER, A. W. J. PLEUMEKERS, \\ W. BASSIE and I. C. BALVERT-GEERS \\ (Department of Organic Chemistry, Catholic University, \\ Toernooiveld, Nijmegen, The Netherlands)
}

\begin{abstract}
The octadecapeptide amide I and the tetracosapeptide II containing homoarginine in position 8 have been synthesized according to a generally approved scheme. As a new feature, the hydroxyl functions of the serine and tyrosine residues were protected in the synthesis of the $N$-terminal decapeptide. The latter, presumably by its higher solubility in organic solvents, afforded the protected end products in an improved yield. For complete deprotection, however, acid-treatment of these compounds had to be extended over longer periods than in the absence of the ether functions.
\end{abstract}

\section{Introduction}

The adrenal cortex and fat cells are stimulated to either steroidogenesis or lipolysis by the adenohypophysal hormone ACTH, which is composed of 39 amino acid residues. The aminoterminal part of this sequence comprising 24 amino acid residues also displays full biological activity and even the shorter sequence covering the aminoterminal octadecapeptide suffices to exert the effects mentioned. Apparently, all structural requirements essential for biological activity are present in the latter.

On account of experiments, in which a competitive inhibitory action on stimulated steroidogenesis was ascribed to smaller ACTH fragments comprising the basic core (the sequence 15-18), the occurrence of two indispensable loci was supposed by Schwyzer ${ }^{1}$ and by Hofmann ${ }^{2}$ in fully active corticotrophic peptides. According to their hypothesis,

1 R. Schwyzer, P. Schiller, S. Seelig and G. Sayers, FEBS Letters 19, 232 (1971).

${ }^{2} K$. Hofmann, W. Wingender and F. M. Finn, Proc. Nat. Acad. Sci. USA 67, 829 (1970). 
biological information is contributed by the sequence $5-10$, whereas binding of the hormone is induced by the basic sequence. Consequently, the purport of these two "sychnological words"3 should be of differing importance.

Our previous investigations on ACTH-analogues in which arginyl residues were replaced by ornithyl groups fit very well into this hypothesis:

a) the single replacement of arginine in position 8 by ornithine ${ }^{4}$ reduced the biological activity to a very low level;

b) similar substitutions of the basic core, however, did not affect steroidogenesis and lipolysis ${ }^{5 a}$ and even replacement of the entire sequence $15-18$ by tetraornithine failed to influence the hormonal ability of the analogue profoundly ${ }^{5 b}$.

Recently, with the analogues I and II we found that substitution in position 8 by homoarginine leads to compounds exhibiting a surprising activity on steroidogenesis and lipolysis in in vitro and in vivo experiments ${ }^{6}$. The analogues I and II* are to be considered as derivatives of the weakly potent analogues that arise upon insertion of lysine ${ }^{7}$ or ornithine in position 8 . The aim of this communication is the description of the underlying syntheses.

(I) H-Ser-Tyr-Ser-Met-Glu-His-Phe-Har-Trp-Gly-Lys-Pro-Val-Lys-Lys-Lys-Lys- $\mathrm{NH}_{2}$

(II) H-Ser-Tyr-Ser-Met-Glu-His-Phe-Har-Trp-Gly-Lys-Pro-Val-Lys-Lys-Arg-Arg-ProVal-Lys-Val-Tyr-Pro-OH

\section{Synthetic Approach}

In accordance with the general procedure recommended for the synthesis of corticotrophic peptides ${ }^{9}$, the end products I and II were obtained in protected form by a carbodiimide mediated coupling,

\footnotetext{
* Designation and abbreviation according to the IUPAC-IUB commission on Biological Nomenclature ${ }^{8}$.

3 R. Schwyzer, XII. European Peptide symposion, Reinhardsbrunn (1972).

4 G. I. Tesser and W. Rittel, Rec. Trav. Chim. 88, 553 (1969).

5. G. I. Tesser and R. Schwyzer, Helv. Chim. Acta 49, 1013 (1966).

sb G. I. Tesser and J. T. Buis, Rec. Trav. Chim. 90, 444 (1971).

6 G. I. Tesser, R. Maier, L. Schenkel-Hulliger, P. L. Barthe, B. Kamber and W. Rittel, Acta Endocrin. 74, 56 (1973).

7 D. Chung and C. H. Li, J. Am. Chem. Soc. 89, 4208 (1967).

8 IUPAC-IUB Commission of Biochem. Nomenclature, Biochem. J. 126, 173 (1972).

9 R. Schwyzer and H. Kappeler, Helv. Chim. Acta 46, 1550 (1963).
} 




(III)

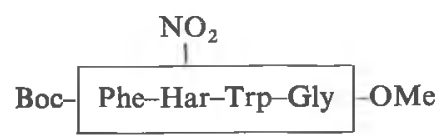

(v)
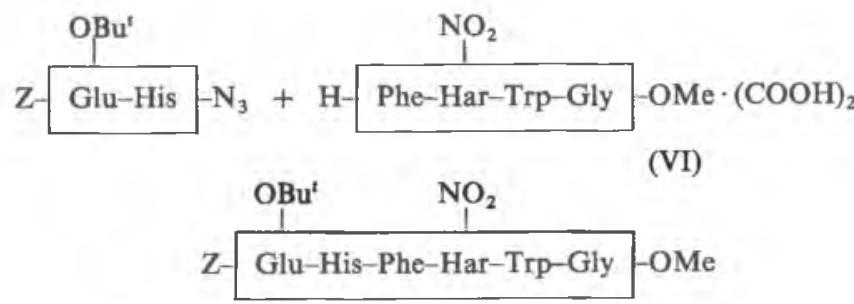

(VII)

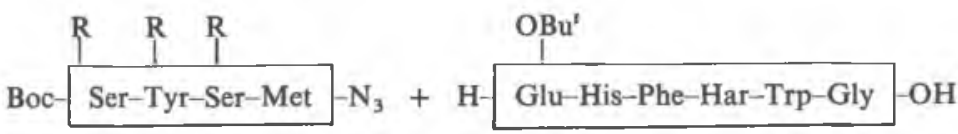

(VIII)

(IX)

a) $\mathbf{R}=\mathrm{H}$

b) $\mathrm{R}=\mathrm{Bu}^{t}$

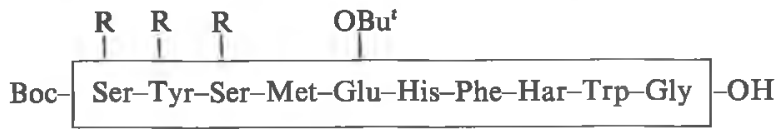

(X) (a and b)

Scheme 1. Synthesis of two protected forms of [Har $\left.{ }^{8}\right]$-Corticotrophin-(1-10)-decapeptide.

generating the glycyl-lysyl bond between the $N$-terminal decapeptide and the pertinent $C$-terminal fragments.

Key intermediate in this investigation was the delicate tetrapeptide ester Boc-Phe-Har( $\left.\mathrm{NO}_{2}\right)$-Trp-Gly-OMe (V, Scheme 1). The best way for its preparation turned out to be a fragment condensation using Mitin's method ${ }^{10}$. Configurational homogeneity was confirmed by a second synthesis, in which the danger of racemization was greatly eliminated by use of the stepwise technique. All intermediates resisted crystallization, tended strongly to discoloration and had to be purified

$10 Y . V$. Mitin and O. V. Glinskaya, Tetrahedron Letters 1969, 5267. 




$$
\begin{aligned}
& \mathrm{Z}-\mathrm{Tyr}-\mathrm{Ser}-\mathrm{OMe}
\end{aligned}
$$

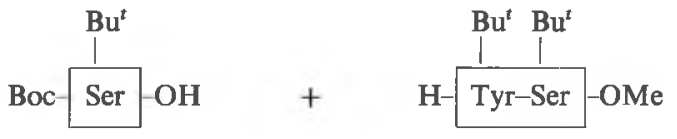

(XII)

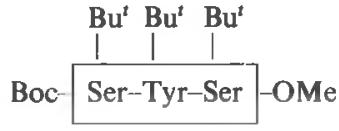

(XIII)

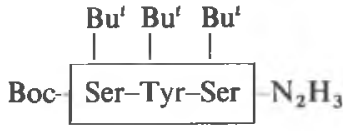

(XIV)

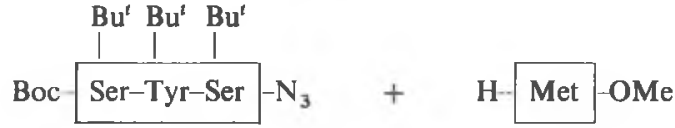

(XV)



(XVII)

Scheme 2. Synthesis of a fully protected corticotrophin-(1-4)-tetrapeptide hydrazide.

by countercurrent distribution. Physical data revealed that the purified products from the two routes were identical.

From this tetrapeptide ester, by two succesive acylations with $\mathrm{Z}-\mathrm{Glu}\left(\mathrm{OBu}^{2}\right)-\mathrm{His}-\mathrm{N}_{3}$ and either Boc-Ser-Tyr-Ser-Met-N $\mathbf{N}_{3}$ or its tristert-butyl ether, the decapeptide (common to both end products) was 



Scheme 3. Synthesis of two forms of protected $\left[\operatorname{Har}^{8}\right]$-corticotrophin-(1-24)-tetracosapeptide and of a protected [Har ${ }^{8}$, Lys $\left.^{17,18}\right]$-corticotrophin-(1-18)-octadecapeptide amide. 
obtained in two different protected forms $\mathrm{Xa}$ and $\mathrm{Xb}$. The requisite tetrapeptide derivative, XVII, was synthesized as summarized in jcheme 2, and has not yet been described. The use of a decapeptide derivative like $\mathrm{Xb}$ might be an improvement in the synthesis of corticotrophins because it possesses the expected higher solubility in organic solvents as compared with $\mathrm{Xa}$, an advantage that resulted in higher yields and purer products after the final condensation. Acylation of the known $C$-terminal fragments XVIII and XXI (as hydrochlorides) with one of the zwitter-ionic decapeptide derivatives was performed with dicyclohexylcarbodiimide and $N$-hydroxysuccinimide (Scheme 3 ). The resulting protected corticotrophins, XIX, XX and XXII, were purified by countercurrent distribution. Cleavage of the tert-butyl functions with $90 \%$ trifluoroacetic acid proceeded smoothly in compound XIX but longer reaction periods were required for the removal of all protective groups from the other two compounds. A similar observation has been recorded in the synthesis of calcitonin ${ }^{11}$, where the enhanced stability of a serine tert-butyl ether was ascribed to the influence of a near-by positive charge. Although no side products arising from this prolonged acid treatment were found, the slow acidolysis evidently diminishes the advantage of the use of tert-butyl ethers as side chain protective groups for hydroxy amino acid residues bearing a labile protective group in the $\alpha$ position.

After exchange of trifluoroacetate ions by acetate ions, the end products I and II were isolated as hexaacetates.

\section{Experimental part}

Scheme 1 .

Boc-Phe-Har $\left(\mathrm{NO}_{2}\right)-$ Trp-Gly-OMe (V)

By fragment condensation

a) Boc-Phe-Har $\left(\mathrm{NO}_{2}\right)-\mathrm{OH}(\mathrm{III}) . \quad \mathrm{N}^{\mathrm{B}}$-Nitrohomoarginine ${ }^{12}$ was esterified with methanol by refluxing a $10 \%$ solution of the amino acid with a mixture of thionyl chloride chloride and methanol $\left(1: 10 \mathrm{v} / \mathrm{v}\right.$ prepared at $\left.-1^{\circ}\right)$ for $2 \frac{1}{2} \mathrm{~h}$. After evaporation of the mixture and some additional evaporations with methanol to remove volatile byproducts,

11 B. Riniker, M. Brugger, B. Kamber, P. Sieber and W. Rittel, Helv. Chim. Acta 52, 1058 (1969).

12 N. Heyboer, G. Heymens Visser and K. E. T. Kerling, Rec. Trav. Chim. 81, 69 (1962). 
the crude ester was obtained as a brittle foamy mass containing 1.36 equivalents of chloride. No unesterified starting material remained.

Acylation to the dipeptide ester was performed in dimethylformamide with Boc-Phe $\mathrm{ONSu}^{13}$ after careful neutralisation of the total amount of chloride present. A $10 \%$ molar excess of the amino component was used to ensure complete conversion of the activated ester. After $3 \mathrm{~h}$. at room temperature, the reaction mixture was filtered and concentrated to a thick syrup which was diluted with water to give an oily precipitate.

The aqueous layer was separated, extracted with ethyl acetate and discarded. The organic phase was added to the oil and the solution was extracted with citric acid, bicarbonate, and sodium chloride solutions and dried.

The product resisted crystallization. A thin layer chromatogram showed a single spot with chlorine-tolidine coinciding with that observed by fluorescense quenching on silica. $\mathrm{R}_{\mathrm{F}}=0.73$ (butanol-acetic acid-water $=10: 1: 3$ ); no starting material remained.

Alkaline hydrolysis of the dipeptide ester again gave a resinous product III exhibiting an $R_{F}$ value of 0.67 in the same solvent system. It was free from methyl ester.

b) $\mathrm{H}$-Trp-Gly-OMe, $\mathrm{HCl}(\mathrm{IV}) . \quad 8.2\left(20\right.$ mmoles) of Z-Trp-Gly-OMe ${ }^{14}$ were suspended in $80 \mathrm{ml}$ of methanol and hydrogenated in the presence of $500 \mathrm{mg}$ of palladium/charcoal $(10 \%)$ and $1.82 \mathrm{ml}(22 \mathrm{mmoles})$ of aqueous concentrated $\mathrm{HCl}$. During the uptake of hydrogen $(480 \mathrm{ml}$ in about $20 \mathrm{~min}$ ), the ester went into solution. Then $2.5 \mathrm{ml}$ of pyridine were added (to prevent acid catalysed oxidative detoriation) and the catalyst was removed by filtration. The solid remaining after evaporation of the solvent was extracted with warm isopropanol. The off-white, noncrystalline salt was kept in the dark. Yield: $6.2 \mathrm{~g}$ (quantitative) of chromatographically pure IV, TS : $\mathbf{R}_{\mathrm{F}}=0.28$ ( $t$-amylalc - isopropanol - water $=67: 26: 7)=0.51(n-\mathrm{BUOH}-\mathrm{AcOH}$-water $=48: 5: 14)$.

c) Condensation to (V): $6.95 \mathrm{~g}$ (14.5 mmoles) of Boc-Phe-Har $\left(\mathrm{NO}_{2}\right)-\mathrm{OH}$ (III) were added to a solution of $4.5 \mathrm{~g}$ (15 mmoles) of H-Trp-Gly-OMe. HCl (IV), $1.53 \mathrm{~g}$ (22.5 mmoles) of imidazole and $2.1 \mathrm{ml}$ (15 mmoles) of triethylamine in $18 \mathrm{ml}$ of dimethylformamide. Subsequently $7.0 \mathrm{~g}(22.5 \mathrm{mmoles})$ of triphenyl phosphite were added and the mixture was stirred for 16 hours at $40^{\circ}$. The brown-coloured solution was then cooled and filtered. Dilution with diisopropyl ether afforded a brown oil, which was dissolved in ethyl acetate. The solution was washed with water, citric acid and bicarbonate solutions, dried with $\mathrm{Na}_{2} \mathrm{SO}_{4}$ and then dropped into a tenfold volume of dry ether. The brownyellow precipitate $(8.96 \mathrm{~g}, 84 \%)$ was filtered and purified by countercurrent distribution in $\mathrm{CHCl}_{3}-\mathrm{CCl}_{4}-\mathrm{MeOH}$-buffer $(3: 1: 4: 2)$; buffer: $19.25 \mathrm{~g}$ of ammonium acetate and $28.5 \mathrm{ml}$ of acetic acid made up to $1000 \mathrm{ml}$ with water. After 375 transfers $7.1 \mathrm{~g}$ of a chromatographically pure product $\left(\mathrm{K}=0.25 ; \mathrm{r}_{\max }=57\right)$ was obtained. $\mathrm{TS}: \mathbf{R}_{\mathrm{F}}=0.54$ $\left(\mathrm{CHCl}_{3}-\mathrm{MeOH}=4: 1\right),=0.93\left(\mathrm{CHCl}_{3}-\mathrm{MeOH}-\mathrm{AcOH}-\mathrm{H}_{2} \mathrm{O}=25: 15: 4: 2\right)$; $[\alpha]_{\mathrm{D}}^{30}-19.8^{\circ}(\mathrm{c}=1, \mathrm{MeOH}) ;$ specific rotation strongly dependent on temperature.

By stepwise synthesis

a) $\mathrm{Boc}-\mathrm{Har}\left(\mathrm{NO}_{2}\right)-\mathrm{Trp}-\mathrm{Gly}$-OMe: in the same way as described for the dipeptide III in the foregoing preparation, Boc-Har $\left(\mathrm{NO}_{2}\right)-\mathrm{OH}$, an amorphous compound obtained from $N^{\mathrm{s}}$-nitrohomoarginine ${ }^{12}$ by acylation with Boc- $\mathrm{N}_{3}$ according to Schnabel ${ }^{15}$, was

13 G. W. Anderson, J. E. Zimmerman and F. M. Callahan, J. Am. Chem. Soc. 86, 1839 1964).

${ }^{14}$ K. Hofmann, M. E. Woolner, G. Spühler and E. T. Schwartz, J. Am. Chem. Soc. 80, 1486 (1958).

15 E. Schnabel, Liebigs Ann. Chem. 702, 188 (1967). 
coupled with H-Trp-Gly-OMe using triphenyl phosphite. The resulting tripeptide ester was precipitated with ether and the oily precipitate purified by extraction of an ethyl cetate solution with water, citric acid, bicarbonate, and saturated sodium chloride solutions. It remained as a yellow oil, that solidified upon cooling $(72 \%)$, and seemed chromatographically pure. TS : $\mathbf{R}_{\mathrm{F}}=0.55\left(\mathrm{CHCl}_{3}-\mathrm{MeOH}=4: 1\right) ;=0.23$ (benzene -acetone $=7: 3$ ). The yellow contamination was eliminated by countercurrent distribution in $\mathrm{CHCl}_{3}-\mathrm{CCl}_{3}-\mathrm{MeOH}$ - buffer $(6: 8: 1: 4)$; composition of the buffer as before. After 387 transfers (214 in an open system and 173 in circulation) a colourless product could be isolated $\left(K=0,36, r_{\max }=105\right)$. A yellow compound remained in the first tubes. Yield of pure protected tripeptide ester $68 \%$, m.p. $122-123,5^{\circ} ;[\alpha]_{\mathrm{D}}^{25}=-13.6^{\circ}$ $\left(c=2.6\right.$ in DMF), $=-21.7^{\circ}(\mathrm{c}=0.98$ in $\mathrm{MeOH})$.

\begin{tabular}{|c|c|}
\hline $\begin{array}{l}\text { Found } \\
\text { Calc for } \mathrm{C}_{27} \mathrm{H}_{38} \mathrm{~N}_{8} \mathrm{O}_{8}(590.63)\end{array}$ & $\begin{array}{l}\text { C } 52.3 ; \text { H } 6.3 ; \text { N } 17.9 \\
\text { C } 52.87 ; \text { H } 6.49 ; \\
\text { N } 18.97\end{array}$ \\
\hline 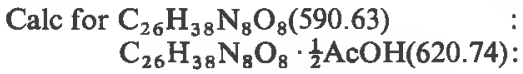 & $\begin{array}{rrr}\text { C } 52.87 ; & \text { H } 6.49 ; & \text { N } 18.97 \\
52.22 ; & 6.49 ; & 18.05\end{array}$ \\
\hline
\end{tabular}

b) $8.85 \mathrm{~g}$ (15 mmoles) of this protected tripeptide ester were dissolved in $20 \mathrm{ml}$ of methanol, and mixed under nitrogen with $20 \mathrm{ml}$ of $5.6 \mathrm{~N} \mathrm{HCl}$ in methanol. Nitrogen was bubbled through the solution for 30 minutes. The solvent was then evaporated in vacuo. To remove volatile constituents, the residue was again dissolved in methanol and evaporated. This procedure was repeated twice with methanol and twice with tert-butanol. Finally the free ester solidified as a brown crystalline mass, which was exceedingly hygroscopic and contained more than one equivalent of hydrochloric acid. The crude tripeptide ester was dissolved in dimethylformamide, giving a slightly acidic solution; it was carefully neutralized by dropwise addition of triethylamine. Then an additional equivalent of triethylamine and $4.5 \mathrm{~g}$ (15 mmoles) of Boc-Phe-OSu were added. The mixture was left overnight at room temperature. It was filtered and the solution was slowly dropped into $250 \mathrm{ml}$ of water, with stirring. Filtration gave $9.8 \mathrm{~g}(89 \%)$ of the crude tetrapeptide ester V. Countercurrent distribution in the system $\mathrm{CHCl}_{3}-\mathrm{MeOH}-$ $\mathrm{CCl}_{4}$-buffer $(3: 4: 1: 2)$ gave after 375 transfers an analytically pure sample in the elements $40-75\left(K=0.18 \mathrm{r}_{\max }=55\right)$. After crystallization from hot ethyl acetate, a gelatinous solid was obtained, melting at $160-163^{\circ},[\alpha]_{\mathrm{D}}^{29}=-18.9^{\circ}(\mathrm{c}=1.05$ in $\mathrm{MeOH}) ; \mathrm{TS}: \mathbf{R}_{\mathbf{F}}=0,61\left(\mathrm{CHCl}_{\mathbf{3}}-\mathrm{MeOH}=4: 1\right) ;=0.73(\mathrm{BuOH}-\mathrm{AcOH}-$ water $=10: 1: 3$ ).

$$
\begin{array}{lrrr}
\text { Found } & \text { C } 57.25 ; & \mathrm{H} 6.4 ; & \mathrm{N} 17.1 \\
\text { Calc. for } \mathrm{C}_{35} \mathrm{H}_{47} \mathrm{~N}_{9} \mathrm{O}_{9}(737.83): & 56.98 ; & 6.62 ; & 17.09 .
\end{array}
$$

$\mathrm{H}$-Phe-Har $\left(\mathrm{NO}_{2}\right)$-Trp-Gly-OMe (VI). $7.38 \mathrm{~g}$ (10 mmoles) of the former product were deprotected with methanolic $\mathrm{HCl}$ as described for the corresponding tripeptide ester. Evaporation in vacuo left a dark oil. The ester hydrochloride was converted into the free amine by the procedure given by Schwyzer ${ }^{16}$. The resulting yellow solid was dried in air yielding $5.35 \mathrm{~g}(84 \%)$ of VI. The free base could be converted into a crystalline salt by treatment of its methanolic solution $(20 \%)$ with oxalic acid in methanol .Again a brown oil separated, which crystallized upon cooling in the refrigerator overnight. The solid was again dissolved in methanol, enough to give a $4 \%$ solution and reprecipitated by addition of isopropanol. Repetition of this procedure yielded an analytically pure product. TS : $\mathrm{R}_{\mathrm{F}}=0.27(\mathrm{BuOH}-\mathrm{AcOH}-$ water $=10: 1: 3) ;[\alpha]_{\mathrm{D}}^{25}=-10.3$ $(c=1, \mathrm{MeOH})$.

16 R. Schwyzer and H. Kappeler, Helv. Chim. Acta 44, 1991 (1961). 
Part of this material was subjected to countercurrent distribution over 240 transfers. The product migrated as a single peak in the system $n$-butanol-petroleum ether (60-80)acetic acid - water $=4: 1: 1: 4\left(\mathrm{~K}=0,54\right.$ and $\left.r_{\max }=27\right)$. It was isolated by lyophiliza tion from tert.-butanol.

Found : C $58.9 ;$ H $5.7 ;$ N 17.25.

Calc. for $\mathrm{C}_{30} \mathrm{H}_{39} \mathrm{~N}_{9} \mathrm{O}_{7}-\mathrm{C}_{2} \mathrm{H}_{2} \mathrm{O}_{4}$ : $58.82 ; \quad 5.68 ; \quad 17.32$.

$\mathrm{Z}-\mathrm{Glu}\left(\mathrm{OBu} \mathrm{t}^{\mathrm{t}}\right)$-His-Phe-Har $\left(\mathrm{NO}_{2}\right)-\mathrm{Trp}-\mathrm{Gly}-\mathrm{OH}(\mathrm{VII})$. Acylation of the tetrapeptide ester VI with benzyloxycarbonyl- $\gamma$-tert-butoxyglutamyl-histidine azide was carried out with slight modifications according to Schwyzer ${ }^{16}$; tert-butyl nitrite was used as the source of nitrosonium ions as described by Honzl and Rudinger ${ }^{17}$ and the azide was used in situ. The crude hexapeptide ester was produced in nearly quantitative yield and was hydrolyzed without further characterization by alkaline saponification. The free acid VII appeared to be more readily soluble than the corresponding peptide derivative containing nitroarginine $\mathrm{e}^{16}$ : it precipitated incompletely on acidification of the alkaline reaction mixture. By concentration of the mother liquor, however, a second precipitate was obtained giving a total yield of $80 \%$ based on the amount of tetrapeptide ester used. Although no contaminants could be detected on TLC, the product stubbornly resisted complete hydrogenolysis in the next step, unless purified by countercurrent distribution. In the solvent system $\mathrm{CHCl}_{3}-\mathrm{MeOH}_{-} \mathrm{CCl}_{4}-$ buffer $(7: 10: 2: 4)$ after 115 transfers, the compound was located in the elements $55-80\left(\mathrm{~K}=1.4 \mathrm{r}_{\max }=67\right)$. The purified product VII melted at $201-204^{\circ},[\alpha]_{\mathrm{D}}^{25}=11.4^{\circ}(\mathrm{c}=1.03$ in $\mathrm{AcOH} 90 \%) ;=-23.6$ $(\mathrm{c}=2, \mathrm{DMF}) . \quad \mathrm{TS}: \mathbf{R}_{\mathbf{F}}=0.34(\mathrm{BuOH}-\mathrm{AcOH}-$ water $=10: 1: 3) ;=0.34$ ( $t$-amyl alcohol-isopropanol-water $=51: 21: 28) ;=0.56(s-\mathrm{BuOH}-\mathrm{AcOH}-$ water $=$ $67: 10: 23) ;=0.27($ EtOAc-Pyr $-\mathrm{AcOH}-$ water $=62: 21: 6: 11)$.

$H$-Glu $\left(O B u^{\mathrm{t}}\right)-H i s-P h e-H a r-T r p-G l y-O H(I X)$. For the removal of $N$-protecting groups, the hexapeptide derivative VII was dissolved in peroxide-free acetic acid $(90 \%)$ and hydrogenated in the presence of palladium charcoal (10\%). Apparently, hydrogenolysis of the benzyloxycarbonyl group proceeded much faster than that of the nitro group: following the progress of the reaction chromatographically on Kieselgel-G (Merck) in methanol, the protected peptide $\left(R_{F}=0.8\right)$ appeared to be converted into an intermediate $\left(R_{F}=0.5\right)$ containing the nitroguanidino function before the end product $\left(\mathrm{R}_{\mathrm{F}}=\mathbf{0 . 2}\right)$ arose. After 30 hours the reaction was complete and slightiy more than the theoretical amount of hydrogen had been taken up. The solution was filtered, the solvent evaporated and the residue dissolved in methanol. Dilution with ether gave the partially protected hexapeptide IX in nearly quantitative yield. $[\alpha]_{\mathrm{D}}^{22}=-24.8^{\circ}(\mathrm{c}=1 \mathrm{DMF})$, $=12.5^{\circ}(\mathrm{c}=1,90 \% \mathrm{AcOH}) ; \mathrm{TS}: \mathrm{R}_{\mathrm{F}}=0.11(\mathrm{sec}-\mathrm{BuOH}-\mathrm{AcOH}-$ water $=67: 10: 23)$, $=0.32(n-\mathrm{BuOH}-\mathrm{Pyr}-\mathrm{AcOH}-$ water $=40: 24: 6: 30),=0.47\left(\mathrm{CHCl}_{3}-\mathrm{MeOH}-17 \%\right.$ $\mathrm{NH}_{3}=41: 41: 18$ ). Electrophoresis on celluiose at $\mathrm{pH}=4.6$ (pyridine acetate) revealed one spot, moving towards the cathode.

Boc-Ser-Tyr-Ser-Met-Glu(OBu $\left.{ }^{\mathfrak{t}}\right)$-His-Phe-Har-Trp-Gly-OH (Xa). According to Schwyzer's procedure ${ }^{16}$, this compound was synthesized from $0.60 \mathrm{~g}(1 \mathrm{mmole})$ of Boc-Ser-Tyr-Ser-Met- $\mathrm{N}_{2} \mathrm{H}_{3}$ and $0.68 \mathrm{~g}(0.71 \mathrm{mmole})$ of the hexapeptide derivative IX, using sodium nitrite. The yield, after crystallization from hot $90 \%$ methanol was $0.53 \mathrm{~g}$ $(51 \%) ;[\alpha]_{\mathrm{D}}^{22}=-16.4^{\circ}(\mathrm{c}=0.7 \mathrm{AcOH}) ; \mathrm{TS}\left(\right.$ Kieselgel-G, Merck): $\mathbf{R}_{\mathrm{F}}=0.25(\mathrm{BuOH}-$ $\mathrm{AcOH}$-water $=10: 1: 3$ ).

17 J. Honzl and J. Rudinger, Coll. Czech. Chem. Commun. 26, 2333 (1961). 
$B o c-S e r\left(B u^{t}\right)-T y r\left(B u^{t}\right)-S e r\left(B u^{t}\right)-M e t-G l u\left(O B u^{t}\right)-H i s-P h e-H a r-T r p-G l y-O H$ (Xb). $1.04 \mathrm{~g}$ (1.36 mmole) of the protected tetrapeptide hydrazide (XVIII, scheme 2) was onverted into the corresponding azide VIIIb and coupled with $1.3 \mathrm{~g}(1.36 \mathrm{mmole})$ of the hexapeptide tert-butyl ester acetate according to Honzl and Rudinger's general in situ procedure ${ }^{17}$. The yield was $1.80 \mathrm{~g}(76 \%)$;S : $\mathbf{R}_{\mathrm{F}}=0.33(\mathrm{BuOH}-\mathrm{AcOH}-$ water $=10: 1: 3),=0.36(\mathrm{BuOH}-\mathrm{AcOH}-$ water $=67: 10: 23),=0.50(\mathrm{sec}-\mathrm{BuOH}-$ isopropanol $-9 \%$ monochloroacetic acid $=58: 8: 34),=0.70(n-\mathrm{BuOH}-\mathrm{Pyr}-\mathrm{AcOH}-$ water $=38: 24: 8: 30) ;[\alpha]_{\mathrm{D}}^{20}=-14.5^{\circ}(\mathrm{c}=1$, MeOH). The Tyr/Trp ratio $(0.9)$ after treatment with $90 \%$ TFA during 15 minutes points to the presence of about $5 \%$ of the hexapeptide in the crude decapeptide derivative. It was used as such for the preparation of XX and XXII. A sample $(100 \mathrm{mg})$ was subjected to the "short column" chromatographic technique of Hunt and Rigby ${ }^{18}$. With the solvent system butanol - acetic acid water $(67: 10: 23)$ at a pressure of $30 \mathrm{~cm}$ of mercury chromatographically pure material $(67 \mathrm{mg})$ was eluted in a sharp band comprising about $2 \mathrm{ml}$. Even a trace of decapeptide derivative containing oxidized methionine in position 4 was retained. The product gave a correct $\mathrm{Tyr} / \mathrm{Trp}$ ratio.

Scheme 2.

$Z-T y r\left(B u^{\mathrm{t}}\right)-\operatorname{Ser}\left(B u^{\mathrm{t}}\right)-O M e(X I) .2 .76 \mathrm{~g}$ of $\mathrm{N}$-Benzyloxycarbonyl-O-tert-butyltyrosine dicyclohexylammonium salt ${ }^{19}(5 \mathrm{mmoles})$ and $1.06 \mathrm{~g}$ of $O$-tert-butylserine methyl ester monohydrochloride (from the corresponding benzyloxycarbonyl compound ${ }^{18}$, after hydrogenolysis and acidification with etheral $\mathrm{HCl}$ ) were dissolved in $30 \mathrm{ml}$ of chloroform. The solution was cooled to $0^{\circ}$ and $1.03 \mathrm{~g}$ ( 5 mmoles) of dicyclohexylcarbodiimide were added.

The reaction mixture was left in a refrigerator for 16 hours and filtered. The filtrate was evaporated in vacuo, the residue triturated with ether, filtered and the solvent was again removed in vacuo. The crude, crystalline dipeptide ester was dissolved in ethyl acetate and its solution extracted with water, citric acid solution (5\%), saturated bicarbonate solution and dried. The product was further purified by crystallization from ether by the addition of petroleum ether $(60-80)$. Yield: $2.35 \mathrm{~g}(86 \%) ;[\alpha]_{\mathrm{D}}^{25}=+5.4^{\circ}$ $(c=1, \mathrm{MeOH})$. Chromatographically homogeneous, $\mathrm{TS}: \mathbf{R}_{\mathbf{F}}=0.73\left(\mathrm{CHCl}_{3}-\mathrm{MeOH}=\right.$ $4: 1)$, fluorescence quenching coincident with the chlorine-tolidine positive spot.

$\begin{array}{ll}\text { Found } & \text { C } 65.5 ; \\ \text { Calc. for } \mathrm{C}_{29} \mathrm{H}_{40} \mathrm{~N}_{2} \mathrm{O}_{7}(528.6 ; \mathrm{N} 5.4 \text {. }\end{array}$

$\operatorname{Boc}-\operatorname{Ser}\left(B u^{\mathrm{t}}\right)-T y r\left(B u^{\mathrm{t}}\right)-\operatorname{Ser}\left(B u^{\mathrm{t}}\right)-N_{2} H_{3}(X I V)$.

a) Methyl ester (XIII), $2.73 \mathrm{~g}$ (5.16 mmoles) of the preceeding compound were rapidly hydrogenated in methanol using $300 \mathrm{mg}$ of palladium/charcoal $(10 \%)$. The uptake of hydrogen stopped abrubtly when $125 \mathrm{ml}$ had been absorbed $(100 \%)$. An equivalent amount of $\mathrm{N}$-butyloxycarbonyl- $\mathrm{O}$-tert-butylserine ${ }^{18}$ was added to the filtered methanolic solution. Subsequently the mixture was evaporated to dryness, the residue dissolved in dimethylformamide (about $15 \mathrm{ml}$ ) containing $0.56 \mathrm{~g}$ of $N$-hydroxysuccinimide and the solution cooled to $-10^{\circ} \mathrm{C}$. Then, with stirring, $1.03 \mathrm{~g}$ (5 mmoles) of dicyclohexylcarbodiimide were added. Stirring was continued at $-10^{\circ}$ during 2 hours before the reaction mixture was placed in the refrigerator. After 16 hours, the cold solution was filtered and evaporated in vacuo. The residue, upon dissolution in ethyl acetate, deposited

18 B. J. Hunt and W. Rigby, Chem. and Ind. 1967, 1868.

19 E. Wünsch and J. Jentsch, Chem. Ber. 97, 2490 (1964). 
a small amount of dicyclohexylurea which was removed by filtration. The filtrate was extracted with water, citric acid and bicarbonate solution as above and, after drying. left the product as an oil on evaporation. It changed into a crisp foam upon drying in high vacuum and proved chromatographically pure TS : $\mathbf{R}_{F}=0.78$ (chloroform-benzene $=1: 1$ ). Yield: $94.2 \%$.

b) Hydrazide (XIV). $2.85 \mathrm{~g}$ (4.5 mmoles) of the methyl ester were dissolved in $15 \mathrm{ml}$ of methanol, containing $1.46 \mathrm{ml}$ (13.5 mmoles) of hydrazine hydrate and left for three days at room temperature. The hydrazide crystallized upon addition of water and appeared pure on TLC. It was dried in a vacuum desiccator over concentrated $\mathrm{H}_{2} \mathrm{SO}_{4}$. For analysis it was crystallized once from aqueous methanol. $[\alpha]_{\mathrm{D}}^{23}=-3.0^{\circ}(\mathrm{c}=1$, $\mathrm{MeOH})$.

Found : C $59.8 ; \mathrm{H} 8.5 ; \mathrm{N} 11.0$.

Calc. for $\mathrm{C}_{32} \mathrm{H}_{55} \mathrm{~N}_{5} \mathrm{O}_{8}(637.80)$ : $\mathrm{C} 60.26 ; \mathrm{H} .8 .69 ; \mathrm{N} 10.98$.


going protected hydrazide were dissolved in $20 \mathrm{ml}$ of dimethylformamide, cooled to $-30^{\circ}$ and acidified with $5.5 \mathrm{mmoles}$ of dry $\mathrm{HCl}$ dissolved in peroxide-free dioxane (3.04 $\mathrm{ml}$ of a $1.81 \mathrm{~N}$-solution). $0.27 \mathrm{ml}$ of tert-butyl nitrite was then added dropwise and the temperature was raised to $-15^{\circ}$. After 10 minutes, the acid present was carefully neutralised by addition of $0.77 \mathrm{ml}$ ( $5.5 \mathrm{mmoles})$ of triethylamine. To the azide solution, a cooled solution of $0.44 \mathrm{~g}$ of methionine methyl ester hydrochloride ( $2.2 \mathrm{mmoles})$ in $20 \mathrm{ml}$ of dimethylformamide and finally $0.31 \mathrm{ml}(2.2 \mathrm{mmoles})$ of triethylamine were added. The reaction mixture was left in the refrigerator for three days, filtered to remove triethylammonium chloride, and evaporated in a high vacuum. The residue was dissolved in peroxide-free ether and extracted with water, bicarbonate, citric acid, and concentrated sodium chloride solutions. Upon evaporation $1.44 \mathrm{~g}(93.5 \%)$ of a foamy solid remained, melting at $100-102^{\circ}$. It was chromatographically pure. TS : $\mathbf{R}_{\mathbf{F}}=0.86$ (butanol-acetic acid - water $=4: 1: 1) ;[\alpha]_{\mathrm{D}}^{25,2}=-7.3^{\circ}(\mathrm{c}=1, \mathrm{MeOH})$.

Found : C $59.6 ; \mathrm{H} 8.3 ; \mathrm{N} 7.5 ; \mathrm{S} 4.2$.

Calc. for $\mathrm{C}_{38} \mathrm{H}_{64} \mathrm{~N}_{4} \mathrm{O}_{10} \mathrm{~S}(768.99)$ : C 59.53; $\mathrm{H} 8.39 ; \mathrm{N} 7.29 ; \mathrm{S} 4.17$.

$\operatorname{Boc}-\operatorname{Ser}\left(B u^{\imath}\right)-T y r\left(B u^{\imath}\right)-\operatorname{Ser}\left(B u^{t}\right)-M e t-N_{2} H_{3} \quad(X V I I) .6 .80 \mathrm{~g}(8.83 \mathrm{mmoles})$ of the preceeding protected tetrapeptide methyl ester were dissolved in $25 \mathrm{ml}$ of methanol containing 3 equivalents of hydrazine hydrate $(1.29 \mathrm{ml})$. The mixture was left at room temperature for three days. Water was added to insipient turbidity and crystallization occurred immediately. Filtration of the cooled suspension afforded $5.38 \mathrm{~g} \mathrm{(79 \% )} \mathrm{of} \mathrm{the}$ hydrazide melting at $190-192^{\circ}$. Chromatographically homogeneous $\mathrm{TS}: \mathbf{R}_{\mathbf{F}}=0.86$ (chloroform-methanol $=4: 1) ;[\alpha]_{\mathrm{b}}^{20}=-6.5^{\circ}(\mathrm{c}=1, \mathrm{MeOH})$.

Found : C $58.1 ; \mathrm{H} 8.3 ; \mathrm{N} 10.5 ; \mathrm{S} 4.1$.

Calc. for $\mathrm{C}_{37} \mathrm{H}_{64} \mathrm{~N}_{6} \mathrm{O}_{9} \mathrm{~S}(768.98)$ : C 57.79; $\mathrm{H} 8.39 ; \mathrm{N} \mathrm{10.93;} \mathrm{S} \mathrm{4.17.}$

Scheme 3.

Protected [Har $\left.{ }^{8}\right]-\beta$-corticotrophin-(1-24)-tetracosapeptides (XIX and XX) and [Har ${ }^{8}$, Lys ${ }^{17,18}$ ]- $\beta$-corticotrophin-(1-18)-octadecapeptide amide (XXII)

Condensation of the decapeptide derivatives $\mathrm{Xa}$ and $\mathrm{b}$ to the tetradecapeptide derivative $\mathrm{XVIII}^{9}$ and the acylation of the partially protected octapeptide amide XXI with Xb was performed by analogy with the procedure of Riniker $^{20}$.

20 B. Riniker and W. Rittel, Helv. Chim. Acta 53, 513 (1970). 
The tetracosapeptide derivative XIX was purified by countercurrent distribution in the system $\mathrm{CHCl}_{3}-\mathrm{CCl}_{4}-\mathrm{MeOH}$-buffer (= 5:2:8:4-for buffer composition see under $\mathrm{V}$ ). Ifter 250 transfers, pure material was located in the elements $55-76\left(\mathrm{~K}=0.34, \mathbf{r}_{\max }=64\right)$. The yield was 44\%, TS: $\mathbf{R}_{\mathrm{F}}=0.26$ (BuOH-AcOH-water $\left.=10: 1: 3\right),=0.30$ (EtOAc-Pyr-AcOH-water = 62:21:6:11). With the latter system, the presence of the corresponding sulphoxide derivate $\left(R_{F}=0.20\right.$ about $5 \%$ was detected in the product.

The compounds XX and XXII, arising from the decapeptide derivative containing protected hydroxyl functions (Xb), were isolated in a nearly pure state on evaporation of the reaction mixture and treatment with ethyl acetate. Subsequent countercurrent distribution of the tetracosapeptide $\mathrm{XX}$ in the same system over 450 transfers $(K=0.02$, $\mathbf{r}_{\max }=7$ ), gave pure material in $70 \%$ yield. $\mathrm{TS}: \mathbf{R}_{\mathrm{F}}=0.27$ (EtOAc-Pyr-AcOH-water $=$ $62: 21: 6: 11)$, free from sulphoxide. $[\alpha]_{\mathrm{D}}^{25}=54^{\circ}(\mathrm{c}=0.587, \mathrm{AcOH} 80 \%)$.

The protected octadecapeptide amide XXII was purified in the same manner with the system $\mathrm{CHCl}_{3}-\mathrm{CCl}_{4}-\mathrm{MeOH}$-buffer $(7: 4: 10: 3), 222$ transfers $\left(\mathrm{K}=0.22, \mathbf{r}_{\max }=40\right)$. Yield $75 \%$ TS: $\mathbf{R}_{\mathrm{F}}=0.63$ (EtOAc-Pyr-AcOH-water $=62: 21: 6: 11$ ), $=0.73$ $\left(\mathrm{CHCl}_{3}-\mathrm{MeOH}=3: 1\right) .[\alpha]_{\mathrm{D}}^{25}=29^{\circ}(\mathrm{c}=0.770, \mathrm{AcOH} 80 \%)$.

Deprotection of $X I X, X X$ and $X X I I:\left[H a r^{8}, L_{y s}{ }^{17,18}\right]-\beta-c o r t i c o t r o p h i n-(1-18)-$ ocradecapeptide amide (I) and [Har $\left.{ }^{8}\right]-\beta$-corticotrophin-(1-24)-tetracosapeptide (II)

Removal of the protective groups from the three compounds was effected with $90 \%$ trifluoroacetic acid. Prior to use, the reagent was distilled from pure methionine $(250 \mathrm{mg} /$ $100 \mathrm{ml}$ ) under nitrogen, to ensure the absence of trace amounts of peroxides. The reaction was carried out in the dark at room temperature in an atmosphere of nitrogen.

Chromatographical estimation of the time required for the removal of the protective groups from the three compounds revealed that compound XIX was set free within 15 minutes as expected but that much longer times were necessary for the removal of all protective groups from XX and XXII. Both compounds gave two intermediates each which were believed to be the mono- and bis-tert-butyl ethers of the otherwise deprotected peptides. In the description of the chromatographic observations (see below) the spots corresponding to these compounds are referred to as "transient spots". Complete removal of the ether functions required 8 hours for compound XX and 6 hours for XXII.

Under the conditions specified, $50 \mathrm{mg}$ batches of the latter compounds were deprotected. The reaction mixture was concentrated after the appropriate period and the product was precipitated with anhydrous, peroxide-free ether. The solid trifluoroacetates were dissolved in $0.1 \mathrm{~N}$-acetic acid and filtered through a column containing a weak ion exchanger MerckII, acetate cycle. Eluate fractions were pooled till the Folin-Ciocalteux reaction became negative, the solution was lyophylized and the product dried in vacuo. The yields were $95 \%$ for I and $93 \%$ for II.

The chromatographic examinations with respect to the completeness of the deprotection and the occurrence of oxidation (of methionine in position 4) were carried out on hand-made alumina thin layer plates (TA: Alumina Camag, with 12\% of gypsum added) after separation with the system BuOH-AcOH-Pyr-water (38:8:24:30). The spots were detected with the chlorine-tolidine test, after the plates had been sprayed with concentrated ammonia and dried (for removal of residual pyridine).

Compound I, TA: $\mathbf{R}_{\mathrm{F}}=\mathbf{0 . 2 3}$ (after oxidation 0.13), transient spots due to tert-butyl ethers 0.38 and 0.48 ; on cellulose (TC) with the same solvent system: $R_{F}=0.43$ (after oxidation 0.26 ), transient spots at 0.57 and 0.63 ; TA, as above, with the solvent BuOHAcOH-water $(67: 10: 23): \mathrm{R}_{\mathrm{F}}=0.09$ transient spots at 0.24 and 0.39 .

Compound II, TA: $R_{F}=0.43$ (after oxidation 0.29 ), transient spots at 0.49 and 0.53 ; TC: $\mathbf{R}_{\mathbf{F}}=0.61$ (after oxidation 0.37 ), transient spots at 0.65 and 0.70 ; TA: 0.24 , transient spots at 0.43 and 0.53 (BuOH-AcOH-water $=67: 10: 23$ ). 
Amino acid analyses were carried out on samples of the deprotected compounds after hydrolysis with $6 N-\mathrm{HCl}$ (diluted "Supra-pur" quality from Merck) for 25 hours at $105^{\circ}$ Results were in accordance with the expected formulae.

\section{Acknowledgement}

We are grateful to Prof. Dr. R. J. F. Nivard for the benefit of stimulating discussions. The expert cooperation from Mr. M. G. J. Buys, who carried out the amino acid analyses and from Mr. J. Diersmann, who performed the elemental analyses is also respectfully acknowledged.

The investigations have been carried out under the auspices of the Netherlands Foundation for Chemical Research (SON) and with financial aid from the Netherlands Organization for the Advancement of Pure Research (ZWO). 